\title{
Longevity of Breeding Sows in Relation to Leg Weakness Symptoms at Six Months of Age
}

\author{
By B. Jørgensen
}

Danish Institute of Agricultural Sciences, Research Centre Foulum, Tjele, Denmark.

\begin{abstract}
Jørgensen B: Longevity of breeding sows in relation to leg weakness symptoms at six months of age. Acta vet. scand. 2000, 41, 105-121. - The objective of this study was to evaluate the influence of leg weakness symptoms measured early in life (at 6 months of age) on the longevity of the sows, i.e. the age at culling due to locomotory problems in a Danish pig herd. One hundred and eighty-seven gilts at 6 months of age were selected according to different leg weakness symptoms and were followed until culling and judged for leg weakness once in every gestation using a scale from 1 (normal) to 4 (severe changes). Age at culling, and the main and secondary reasons for culling were recorded. The influence of leg weakness symptoms on longevity was evaluated by survival analysis. Though only $12 \%$ of the gilts showed a stiff locomotion half of the sows had suffered from this and nearly one third had been distinctly lame at some time in their life. Buck-kneed forelegs, upright pasterns, legs turned out, standing under position and swaying hindquarters were associated with stiff locomotion or lameness, whereas weak pasterns on hind legs and splayed digits on forelegs were associated with brisk movement (freedom from locomotor problems). The following leg weakness symptoms at the gilt stage were found to have significant negative effects on longevity: buck-kneed forelegs, swaying hindquarters, and standing under position on hind legs.

pigs; gilts, locomotion; selection programme; survival analysis; culling reasons; Weibull regression model.
\end{abstract}

\section{Introduction}

In the sow population, leg problems are considered to be a welfare concern as a result of the pain they cause, and constitute a major cause of involuntary culling of the animals at an earlier age than the optimal. The size of the problem is apparent from the results of an investigation by (Christensen et al. 1995) of the causes of euthanasia of sows in herds which showed that $28.5 \%$ of the sows being euthanised and delivered to a rendering plant had leg weakness as the primary cause. Other studies found that between $10 \%$ and $25 \%$ of the sows are culled due to locomotory problems (Svendsen et al. 1975, Dagorn \& Aumaitre 1979, Penny 1980, D'Allaire et al. 1987, Stein et al. 1990, Dagorn \& Vaude- let 1993, Cederberg \& Jonsson 1996) making it the second most important reason for culling among sows. Further, because the age at culling is lower for sows being culled due to leg problems than for sows culled due to other problems (Jones 1967, Dagorn \& Aumaitre 1979, Karlberg 1979, D'Allaire et al. 1987, Kangasniemi 1996, Paterson et al. 1996), a decrease in these involuntary cullings would improve the longevity of sows. This could possibly result in an increased average number of piglets per litter because of a decreasing number of first parity sows (Van Steenbergen 1990).

Meat content is an important selection goal in many countries. However, there is an unfavour- 
able genetic correlation between leg weakness and meat content. (Bereskin 1979, Webb et al. 1983, Lodde et al. 1985, Lundeheim 1987, Rothschild et al. 1988, Jørgensen \& Vestergaard 1990). Thereby an increasing incidence of leg problems in sows can be expected and thus a poorer longevity if leg soundness is not considered in breeding. The possibility of reducing the incidence of leg problems genetically exists since a reasonably high heritability of different leg weakness symptoms has been found (Jørgensen \& Vestergaard 1990).

The characteristic symptoms of leg weakness are: buck-kneed position of forelegs, upright or weak pasterns, legs turned out (abduction), standing under position on hind legs, stiff locomotion in front and rear and swaying hindquarters (Nielsen 1973, Grøndalen 1974, Penny 1980, Jørgensen \& Vestergaard 1990). Not all these deviations from a normal leg position and locomotion are thought to have the same effect on the welfare and longevity of the animals. The earlier culling a trait results in, the more important it is to select against it. Differences in age at culling due to leg problems can thus be used as a measure of the relative importance of the traits.

In studies of longevity in cows, 2 types of longevity are considered: true and functional $(D u-$ crocq 1987). True longevity deals with length of productive life, whereas functional longevity measures the importance of involuntary disposal i.e. the ability of a cow to avoid culling because of sterility, lameness, mastitis or other diseases. True longevity is the ability to delay both voluntary and involuntary culling, whereas functional longevity is the ability to delay involuntary culling, calculated by Ducrocq et al. (1988) by adjusting for low milk yield, which is the major reason for voluntary culling in dairy cows. In studies of longevity in sows, both true longevity (Van Steenbergen 1990, Jørgensen \& Sørensen 1998) and a type of functional longe- vity (Jørgensen \& Sørensen 1998) are considered. True longevity resembles the 'cow expression', whereas functional longevity in this case is the ability to delay culling due to locomotory problems, calculated by categorising sows culled for other reasons as censored observations in the survival analyses.

The aim of this investigation was to study the trends in leg weakness symptoms over time and to assess the effects of leg weakness symptoms measured at 6 months of age on the longevity of sows. Traits associated with longevity could be used in a selection programme.

\section{Materials and methods}

A prospective cohort study was carried out in a Danish pig herd. Female pigs were selected at 6 months of age and followed until culling or death. The goal was to select approximately 20 gilts scoring 3 or 4 on a scale from 1 (normal) to 4 (severe changes) for each of 16 leg weakness symptoms. Lame gilts were not selected. We were able to form 11 leg weakness 'cohorts' (Table 1, indicated by X). Further, one control 'cohort' was formed of gilts that scored 1 or 2 for all the symptoms. Each of the animals that was not a control could have several symptoms at the same time, which opened up the possibility of testing for interactions between symptoms. The study was consequently not a cogent cohort study and data were not analysed as such. A total of 187 gilts were included in the experiment, 94 gilts were crossbreeds (Landrace male*Yorkshire female or Yorkshire male*Landrace female) and 93 Yorkshire; of these 21 crossbreeds and 13 Yorkshire gilts were in the control 'cohort'. The 2 'breeds' were not present simultaneously in the herd. The Yorkshire gilts followed the crossbreeds. This influenced the distribution of 'breeds' in the cohorts as the crossbreeds were selected first and Yorkshire was used to fill up the cohorts. The gilts were fed ad libitum in the rear- 
Table 1. Prevalence (\%) and mean score of leg weakness symptoms at 6 months of age. No. of gilts $=187$ $($ Crossbreed $=94$, Yorkshire $=93)$.

\begin{tabular}{|c|c|c|c|c|c|c|c|}
\hline & & \multirow[b]{2}{*}{ Breed } & \multicolumn{4}{|c|}{ Score $^{\mathrm{a}}$ (percent) } & \multirow{2}{*}{$\begin{array}{l}\text { Mean } \\
\text { score }\end{array}$} \\
\hline & & & 1 & 2 & 3 & 4 & \\
\hline \multicolumn{8}{|l|}{ Forelegs: } \\
\hline \multirow[t]{2}{*}{ Buck-kneed } & $\mathrm{X}^{\mathrm{b}}$ & $\mathrm{Cr}^{\mathrm{c}}$ & 54 & 36 & 4 & & 1.47 \\
\hline & & Y & 28 & 36 & 26 & 3 & 2.04 \\
\hline \multirow[t]{2}{*}{ Upright pasterns } & & $\mathrm{Cr}$ & 85 & 6 & 3 & & 1.13 \\
\hline & & Y & 77 & 8 & 8 & & 1.26 \\
\hline \multirow[t]{2}{*}{ Weak pasterns } & $X$ & $\mathrm{Cr}$ & 73 & 10 & 11 & & 1.34 \\
\hline & & $\mathrm{Y}$ & 75 & 10 & 8 & & 1.28 \\
\hline \multirow[t]{2}{*}{ Legs turned out } & & $\mathrm{Cr}$ & 83 & 10 & 1 & & 1.13 \\
\hline & & $\mathrm{Y}$ & 78 & 11 & 4 & & 1.20 \\
\hline \multirow[t]{2}{*}{ Claws uneven } & $\mathrm{X}$ & $\mathrm{Cr}$ & 63 & 22 & 9 & & 1.43 \\
\hline & & $\mathrm{Y}$ & 53 & 20 & 19 & 1 & 1.66 \\
\hline \multirow[t]{2}{*}{ Bursitis carpalis } & & $\mathrm{Cr}$ & 88 & 5 & 1 & & 1.07 \\
\hline & & $\mathrm{Y}$ & 80 & 6 & 6 & 1 & 1.23 \\
\hline \multicolumn{8}{|l|}{ Hind legs: } \\
\hline \multirow[t]{2}{*}{ Standing under } & $X$ & $\mathrm{Cr}$ & 84 & 8 & 2 & & 1.13 \\
\hline & & $\mathrm{Y}$ & 74 & 3 & 14 & 2 & 1.40 \\
\hline \multirow[t]{2}{*}{ Steep hock joints } & $X$ & $\mathrm{Cr}$ & 58 & 18 & 18 & & 1.57 \\
\hline & & $\mathrm{Y}$ & 68 & 10 & 15 & & 1.43 \\
\hline \multirow[t]{2}{*}{ Upright pasterns } & $\mathrm{X}$ & $\mathrm{Cr}$ & 68 & 17 & 9 & & 1.37 \\
\hline & & $\mathrm{Y}$ & 68 & 10 & 15 & & 1.43 \\
\hline \multirow[t]{2}{*}{ Weak pasterns } & & $\mathrm{Cr}$ & 85 & 7 & 2 & & 1.12 \\
\hline & & $\mathrm{Y}$ & 82 & 7 & 4 & & 1.16 \\
\hline \multirow[t]{2}{*}{ Legs turned out } & $\mathrm{X}$ & $\mathrm{Cr}$ & 48 & 38 & 8 & & 1.57 \\
\hline & & $\mathrm{Y}$ & 42 & 31 & 20 & & 1.76 \\
\hline \multirow[t]{2}{*}{ Claws uneven } & $\mathrm{X}$ & $\mathrm{Cr}$ & 25 & 42 & 27 & & 2.02 \\
\hline & & $\mathrm{Y}$ & 66 & 21 & 6 & & 1.35 \\
\hline \multirow[t]{2}{*}{ Bursitis tarsalis } & X & $\mathrm{Cr}$ & 53 & 23 & 18 & & 1.63 \\
\hline & & Y & 61 & 20 & 11 & 1 & 1.48 \\
\hline \multicolumn{8}{|l|}{ Locomotion: } \\
\hline \multirow[t]{2}{*}{ Stiff in front } & & $\mathrm{Cr}$ & 94 & & & & 1.00 \\
\hline & & Y & 88 & 1 & 4 & & 1.10 \\
\hline \multirow[t]{2}{*}{ Stiff in rear } & $X$ & $\mathrm{Cr}$ & 70 & 13 & 11 & & 1.37 \\
\hline & & $\mathrm{Y}$ & 76 & 5 & 11 & 1 & 1.32 \\
\hline \multirow[t]{2}{*}{ Swaying hindquarters } & $X$ & $\mathrm{Cr}$ & 73 & 10 & 11 & & 1.34 \\
\hline & & Y & 73 & 10 & 8 & 2 & 1.34 \\
\hline
\end{tabular}

${ }^{\text {a }}$ Score 1 (normal) to 4 (severe changes)

${ }^{\mathrm{b}}$ Leg weakness groups ('cohorts') with number of gilts scoring 3 or $4>=18$ (pooled for the two breeds) (see Materials and methods section)

${ }^{c}$ Breed: Cr: Crossbreed (LY,YL), Y: Yorkshire

ing period. They were housed in pens with solid floor and dunging area in the rearing period, in boxes with slatted floor in their first gestation, and tied in gestation stalls as sows.
The animals were assessed clinically for leg weakness problems at 6 months of age and late in each pregnancy (between day 70 and day 100). The assessment was done outside the 
Table 2. Mean score and number of sows scoring 3 or 4 for different leg weakness symptoms at 3 different times of life. No. of sows $=187$.

\begin{tabular}{|c|c|c|c|c|c|c|}
\hline & \multicolumn{2}{|c|}{$\begin{array}{l}\text { At } 6 \text { months } \\
\text { of age }\end{array}$} & \multicolumn{2}{|c|}{$\begin{array}{l}\text { Maximal score } \\
\text { over time }\end{array}$} & \multicolumn{2}{|c|}{$\begin{array}{l}\text { Last investigation } \\
\text { before culling }\end{array}$} \\
\hline & mean & $\overline{n_{3+4}}$ & mean & $\mathrm{n}_{3+4}$ & mean & $\mathrm{n}_{3+4}$ \\
\hline \multicolumn{7}{|l|}{ Forelegs: } \\
\hline Buck-kneed & 1.75 & 33 & 2.13 & 57 & 1.53 & 17 \\
\hline Upright pasterns & 1.19 & 11 & 1.71 & 44 & 1.22 & 11 \\
\hline Weak pasterns & 1.31 & 19 & 1.91 & 60 & 1.48 & 26 \\
\hline Legs turned out & 1.17 & 5 & 1.61 & 25 & 1.24 & 8 \\
\hline Claws uneven & 1.54 & 29 & 2.54 & 109 & 1.77 & 40 \\
\hline Bursitis carpalis & 1.15 & 8 & 1.76 & 40 & 1.49 & 24 \\
\hline \multicolumn{7}{|l|}{ Hind legs: } \\
\hline Standing under & 1.26 & 18 & 1.91 & 58 & 1.42 & 24 \\
\hline Steep hock joints & 1.50 & 33 & 1.87 & 54 & 1.20 & 10 \\
\hline Upright pasterns & 1.40 & 24 & 1.48 & 29 & 1.05 & 7 \\
\hline Weak pasterns & 1.14 & 6 & 2.39 & 97 & 1.98 & 65 \\
\hline Legs turned out & 1.67 & 28 & 2.42 & 93 & 1.75 & 35 \\
\hline Claws uneven & 1.69 & 33 & 2.12 & 67 & 1.51 & 17 \\
\hline Bursitis tarsalis & 1.56 & 30 & 2.01 & 61 & 1.53 & 31 \\
\hline \multicolumn{7}{|l|}{ Locomotion: } \\
\hline Stiff in front & 1.05 & 4 & 1.34 & 23 & 1.14 & 8 \\
\hline Stiff in rear & 1.35 & 23 & 2.21 & 91 & 1.49 & 35 \\
\hline Swaying hindquarters & 1.34 & 21 & 2.07 & 65 & 1.51 & 31 \\
\hline \multicolumn{7}{|l|}{ Sows: } \\
\hline Overgrown claws fore & 1.00 & 0 & 1.17 & 7 & 1.04 & 2 \\
\hline Overgrown claws hind & 1.00 & 0 & 1.55 & 30 & 1.27 & 16 \\
\hline $\begin{array}{l}\text { Overgrown claws on accessory } \\
\text { digits fore }\end{array}$ & 1.00 & 0 & 1.57 & 36 & 1.37 & 24 \\
\hline $\begin{array}{l}\text { Overgrown claws on accessory } \\
\text { digits hind }\end{array}$ & 1.00 & 0 & 1.59 & 38 & 1.33 & 21 \\
\hline Local changes $^{\mathrm{a}}$ & 1.01 & 1 & 1.32 & 30 & 1.16 & 15 \\
\hline Lameness $^{\mathrm{a}}$ & 1.01 & 1 & 1.59 & 55 & 1.24 & 22 \\
\hline Splayed digits fore ${ }^{\mathrm{a}}$ & 1.01 & 1 & 1.34 & 32 & 1.12 & 11 \\
\hline Goose-stepping hind legs ${ }^{\mathrm{a}}$ & 1.02 & 2 & 1.18 & 17 & 1.05 & 5 \\
\hline Tendency to slip ${ }^{\mathrm{a}}$ & 1.01 & 1 & 1.39 & 36 & 1.15 & 14 \\
\hline Claw lesions ${ }^{\mathrm{a}}$ & 1.01 & 1 & 1.35 & 33 & 1.08 & 7 \\
\hline Brisk movement ${ }^{\mathrm{a}}$ & 1.00 & 0 & 1.49 & 46 & 1.28 & 26 \\
\hline
\end{tabular}

${ }^{a}$ Score 1 (normal) or 3 (non-normal)

pens or boxes scoring on a scale from 1 (normal) to 4 (severe changes) according to the description by Jørgensen \& Vestergaard (1990). All assessments were made by the author without knowledge of the previous scorings or 'co- hort memberships'. Besides the 16 symptoms in Table 1, the following changes appearing after 6 months of age were recorded in the sows: overgrown claws; overgrown claws on accessory digits; splayed (abducted) digits on fore- 
legs; local changes (abscesses and bursitis at other locations than carpal and tarsal joints); claw lesions (lesions recorded clinically without lifting the legs, i.e. mainly side wall lesions); tendency to slip on hind legs (usually observed when urinating); goose-stepping movements on hind legs; lameness/ sorelegged; brisk movement (the animal galloped voluntarily along when it was let loose) (Table 2).

At culling, the main and secondary (in case of 2) reasons for culling and age were recorded. The decision to cull sows was made by the herd manager without knowledge of the cohort memberships and scorings of the animals. Culling because of poor production was not permitted until after sows had produced their 6 th litter. Culling included emergency culling on farm as well as dispatching of sows to the slaughterhouse. The study was planned to end after the 6th litter at which time the remaining Yorkshire sows were culled. Some of the crossbred sows remained in the herd, however, and were judged for leg weakness until they were culled. To compare the 'breeds' with regard to the number of litters at removal, the crossbreeds were limited to 6 litters. At slaughter, the claws were cut off and the joints from the limbs of the carcasses were collected for subsequent pathological examinations (Jørgensen 2000).

\section{Statistical methods}

Associations between symptoms of leg weakness and some locomotory problems and brisk movement, respectively, were analysed using regression analysis. Locomotory problems were analysed one at a time using the other leg weakness traits as explanatory variables (model 1). A normal distribution was assumed. The maximal scores over time for each sow were used. A backward elimination procedure was used removing the variables one at a time with the highest $p$-value until only variables with a p- value $<0.10$ were left in the model. The procedure PROC REG in SAS was used (SAS Institute Inc. 1989).

The influence of leg weakness symptoms in gilts at 6 months of age on their longevity was analysed by survival analysis using a Weibull regression model. Two analyses were performed: one of the age at culling where locomotory disorders were stated as the main reason and one of the age at culling where locomotory disorders were stated as either the main or secondary reason for culling. Age was analysed as time from 6 months of age until culling. Right censored observations were sows culled for reasons other than locomotory disorders (including 'end of study'). Breed and leg weakness traits were analysed as explanatory variables. The leg weakness traits were analysed as categorical traits. Due to a limited number of score 4 (Table 1), these were added to the score 3 category, ending up with 3 categories (scores 1, 2 and $3+4)$. A backward elimination procedure was used, where variables with the highest $p$ value were removed one at a time, until only variables with a $p$-value $<0.05$ remained in the model. The assumption of Weibull distribution was evaluated in plots of the log of the negative $\log$ of the estimated survival function against $\log$ time. Plots of the Kaplan-Meier estimates are shown in Fig. 2 for the effect of significant leg weakness symptoms on the probability of survival. The procedures PROC LIFEREG and PROC LIFETEST in SAS were used (SAS Institute Inc. 1989).

\section{Results}

Leg weakness symptoms

The prevalence and mean scores of $16 \mathrm{leg}$ weakness symptoms in the premature gilts at 6 months of age divided by 'breed' (Yorkshire and crossbreeds) are shown in Table 1. Some symptoms showed significant 'breed' differences $\left(\chi^{2}\right.$-test $)$, as the crossbreeds scored 

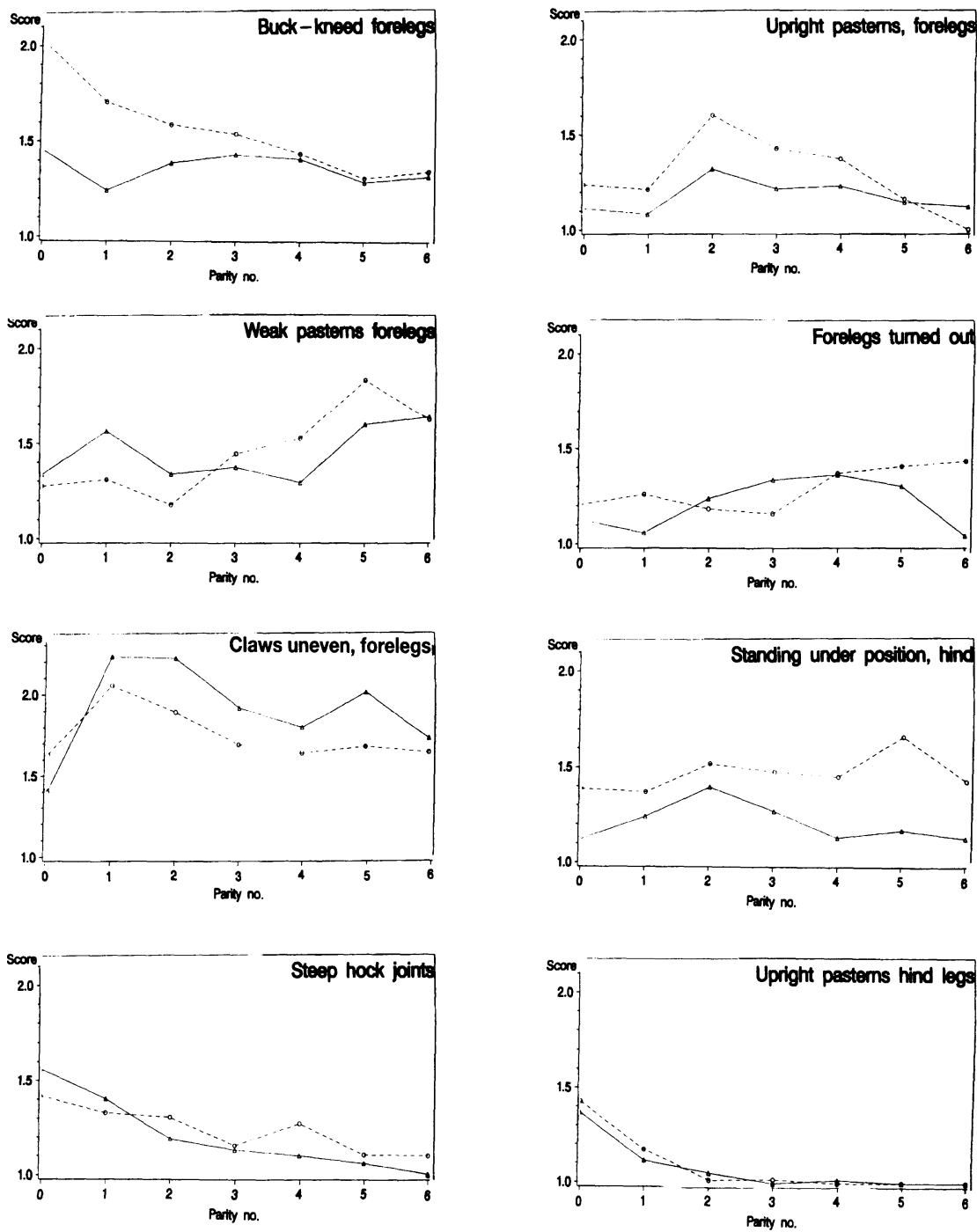

Breed: $\Delta \Delta \triangle L^{\star} Y$ Crossbreed $\theta \theta \ominus$ Yorkshire

No. of animals in Fig. 1

Parity no.

Crossbreed

Yorkshire

$\begin{array}{rr}0 & 1 \\ 94 & 85\end{array}$

2

34

5

70

62

54

49

$61 \quad 52$

44

30

Figure 1 . The trends of the average leg weakness symptoms over time (parity number) by 'breed' up to parity no. 6 . 

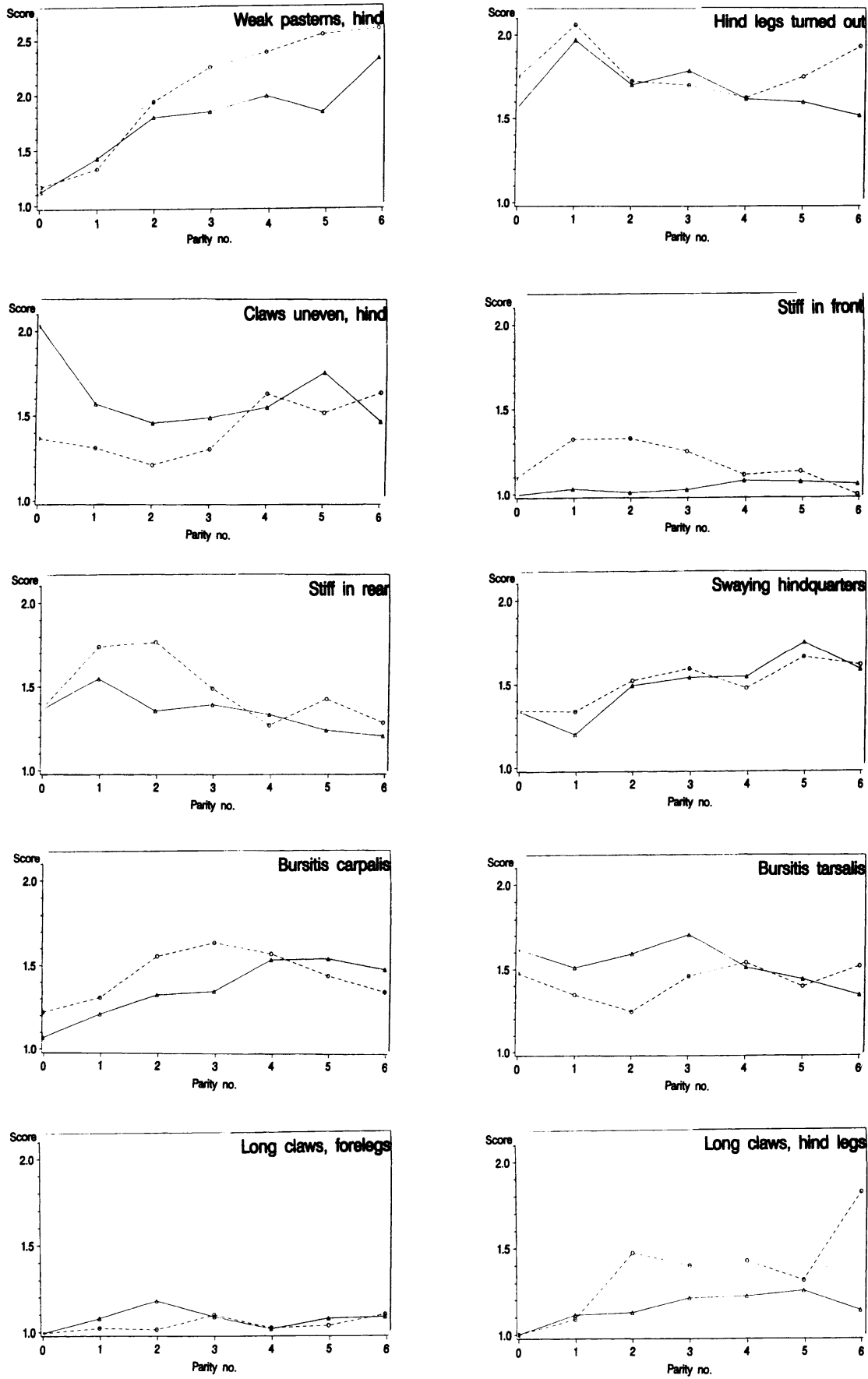

Figure 1. (continued).

Breed: $\triangle \Delta \triangle$ L*Y Crossbreed $\theta \theta \theta$ Yorkshire 

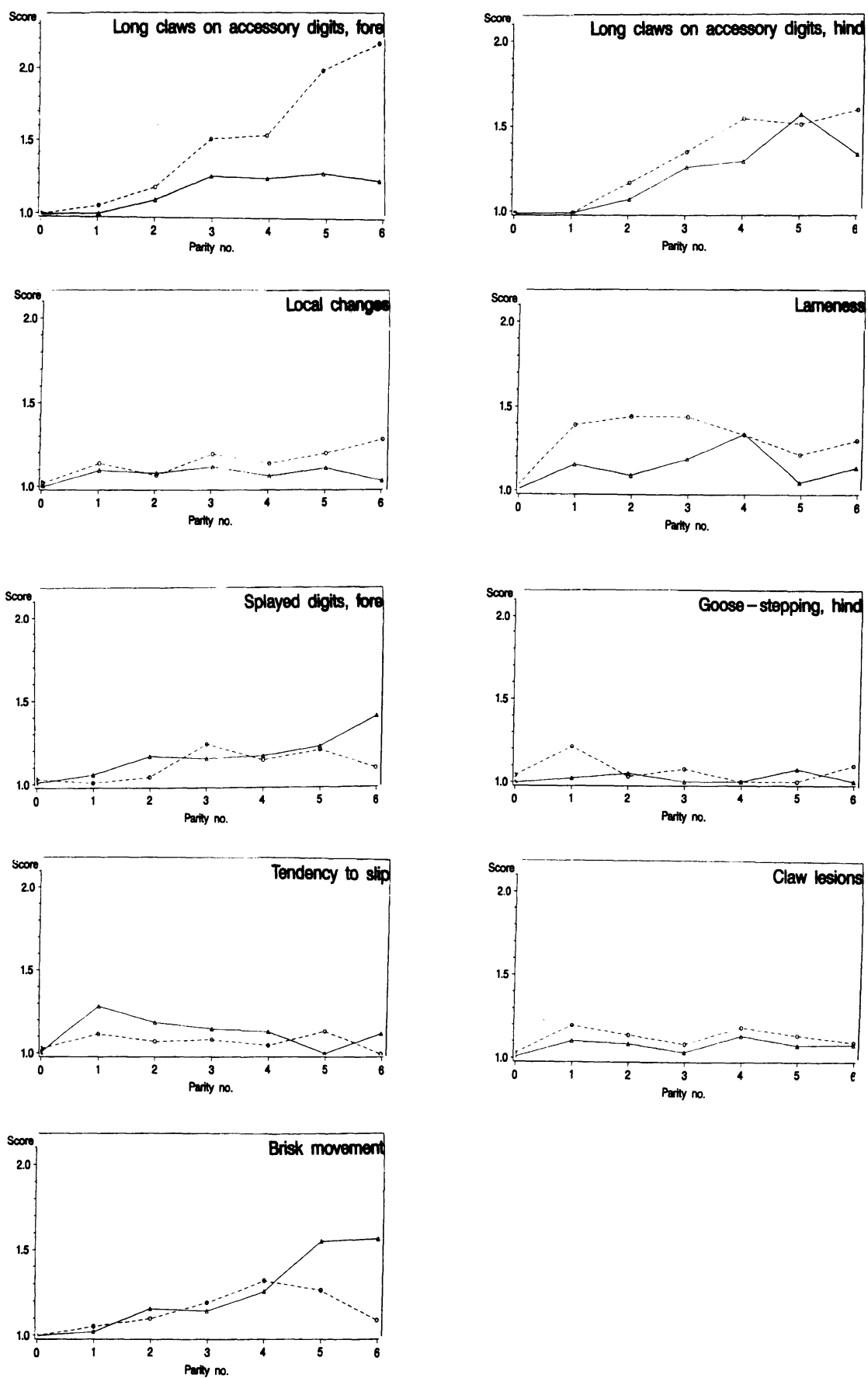

Figure 1. (continued).

Breed: $\Delta \Delta \triangle$ L*Y Crossbreed $\theta \theta \ominus$ Yorkshire 
Table 3. Associations between leg weakness symptoms and some locomotory problems and brisk movement, respectively.

\begin{tabular}{|c|c|c|c|c|c|c|c|c|}
\hline & \multicolumn{2}{|c|}{$\begin{array}{l}\text { Stiff } \\
\text { in front }\end{array}$} & \multicolumn{2}{|c|}{$\begin{array}{c}\text { Stiff } \\
\text { in rear }\end{array}$} & \multicolumn{2}{|c|}{ Lameness } & \multicolumn{2}{|c|}{$\begin{array}{c}\text { Brisk } \\
\text { movement }\end{array}$} \\
\hline & B & $\mathrm{p}$ & B & $\mathrm{p}$ & B & $\mathrm{p}$ & B & $\mathrm{p}$ \\
\hline \multicolumn{9}{|l|}{ Forelegs: } \\
\hline Buck-kneed forelegs & .16 & $* *$ & & & & & & \\
\hline Upright pasterns fore & .14 & $* *$ & & & & & & \\
\hline Forelegs turned out & & & & & .16 & * & & \\
\hline Splayed digits fore & & & & & & & .35 & $* * *$ \\
\hline \multicolumn{9}{|l|}{ Hind legs: } \\
\hline Standing under hind & & & .26 & $* * *$ & .20 & $* *$ & & \\
\hline Upright pasterns hind & .11 & .07 & & & & & & \\
\hline Weak pasterns hind & & & & & & & .11 & $*$ \\
\hline \multicolumn{9}{|l|}{ Locomotion: } \\
\hline Stiff in front & & & .44 & $* * *$ & .26 & $* *$ & & \\
\hline Stiff in rear & .26 & $* * *$ & & & & & -.17 & $* *$ \\
\hline Swaying hindquarters & & & .23 & $* * *$ & & & & \\
\hline Lameness & .16 & ** & & & & & & \\
\hline Goose-stepping hind legs & -.19 & $* *$ & .40 & $* * *$ & & & & \\
\hline Tendency to slip & & & .15 & * & & & & \\
\hline Brisk movement & & & -.19 & $* *$ & & & & \\
\hline Claw lesions & -.16 & ** & & & .37 & $* * *$ & & \\
\hline
\end{tabular}

The maximal scores over time for each sow were used (see Table 2)

$\beta$ - and $p$-values from model 1

higher than Yorkshire for claws uneven on hind legs $(\mathrm{p}<0.001)$, whereas Yorkshire gilts scored higher for buck-kneed forelegs $(\mathrm{p}<0.001)$, standing under position on hind legs $(\mathrm{p}<0.01)$ and hind legs turned out $(\mathrm{p}<0.05)$ (Fig. 1, parity $0)$.

The mean score and number of sows scoring 3 or 4 for different leg weakness symptoms at the first investigation at 6 months of age, at the last investigation before culling, and as the maximal score over time are shown in Table 2 . The data were pooled for the 2 'breeds'. $49 \%$ of the sows (91 out of 187) had suffered from stiff locomotion in the rear of a medium severe or severe degree (scores 3 or 4 ) and 55 sows (29\%) had been distinctly lame at some time in their lives (maximal scores).
The trends of the leg weakness symptoms over time (parity number) for the 2 'breeds' are shown in Fig. 1. The following overall trends were seen:

- symptoms that increased over time were: weak pasterns on fore and hind legs, swaying hindquarters, overgrown claws on accessory digits on fore (in particular Yorkshire) and hind legs, and brisk movement.

- symptoms that decreased over time were: buck-kneed forelegs (in particular Yorkshire), steep hock joints, and upright pasterns on hind legs.

No statistical tests for increasing or decreasing trend were made as the majority of symptoms showed an irregular development. A test for breed differences was not made either as these 
Table 4. Frequency (number of sows) of main and secondary reason for culling by 'breed'.

\begin{tabular}{lccccc}
\hline \multirow{2}{*}{ No. of sows culled } & \multicolumn{2}{c}{ Crossbreed } & & \multicolumn{2}{c}{ Yorkshire } \\
\cline { 2 - 3 } \cline { 5 - 6 } & Main & Secondary & & Main & Secondary \\
\hline Locomotory disorders & 28 & 15 & & 22 & 11 \\
Repeated return to heat & 4 & & & 23 & 3 \\
Non-pregnant & 25 & 1 & & 1 \\
Old age $^{\mathrm{a}}$ & 18 & 4 & & 10 & 6 \\
Miscellaneous $_{\text {Death }}$ & 8 & & & 10 & \\
End of study & 1 & 20 & 93 & 21 \\
\hline Total & 94 & &
\end{tabular}

a see the Materials and methods section

were forced by the study design (see the Materials and methods section).

\section{Associations between leg weakness symptoms and locomotory problems}

In order to investigate which symptoms were associated with locomotory problems (stiff locomotion or lameness) and which had no impact on locomotory problems, a regression analysis was made of the association between the leg weakness symptoms and stiff locomotion (fore and rear), lameness and brisk movement, respectively, using model 1 (Table 3). The maximal scores over time for each sow were used for both the dependent (response) and independent (explanatory) variables, i.e. they were not necessarily present simultaneously, but one variable could have been previous to the other. As shown in Table 3, stiff in front was positively (i.e. unfavourably) associated with buck-kneed forelegs and upright pasterns. Stiff in rear was associated with standing under position on hind leg, swaying hindquarters, goose-stepping movement on hind legs and tendency to slip. Stiff in front, stiff in rear and lameness were mutually associated. Table 3 further demonstrates that animals suffering from lameness had significantly higher scores for forelegs turned out, standing under position on hind, stiff in front and claw lesions at one time or another. Brisk movement was positively (i.e. favourably) associated with weak pasterns on hind legs and splayed digits on forelegs, but was negatively (unfavourably) associated with stiff in rear. Brisk movement did not occur until the second parity (Fig. 1).

\section{Culling reasons}

Reproduction problems (i.e. repeated return to heat and non-pregnant) were the most frequent reasons for culling followed by locomotory disorders (Table 4). Yorkshire sows were more frequently culled due to 'miscellaneous' and 'end of study', whereas only crossbred sows were culled because of 'old age' (see the Materials and methods), but apart from these, no 'breed' differences were seen in the frequency of culling by reason (Table 4 ).

There were large differences between 'breeds' in the mean age and number of litters at removal, as Yorkshire sows were considerably younger and had had fewer litters at culling than crossbreeds ('all reasons') (Table 5). More specifically, this difference was found for 'locomotory disorders' and 'repeated return to heat', because of which Yorkshire sows were 
Table 5. Mean age and number of litters at removal for each removal category and 'breed'.

\begin{tabular}{|c|c|c|c|c|c|c|}
\hline \multirow{2}{*}{ Culling reason $^{\mathrm{a}}$} & & \multicolumn{2}{|c|}{ Crossbreed } & \multicolumn{2}{|c|}{ Yorkshire } & \multirow{2}{*}{$\frac{\text { Significance }^{b}}{\text { p-value }}$} \\
\hline & & mean & s.d. & mean & s.d. & \\
\hline \multirow[t]{2}{*}{ All reasons } & age (months) & 32.6 & 13.8 & 26.0 & 10.6 & $* * * \mathrm{c}$ \\
\hline & litter $n^{\mathrm{d}}$ & 4.1 & 2.3 & 2.9 & 2.2 & $* * *$ \\
\hline \multirow[t]{2}{*}{ Locomotory disorders } & age & 35.4 & 12.0 & 23.0 & 11.6 & $* * *$ \\
\hline & litter no & 4.9 & 2.0 & 2.6 & 2.4 & $* * *$ \\
\hline \multirow[t]{2}{*}{ Repeated return to heat } & age & 28.3 & 7.0 & 13.6 & 3.0 & $* * *$ \\
\hline & litter no & 3.5 & 1.3 & 0.3 & 0.5 & $* * * \mathrm{c}$ \\
\hline \multirow{2}{*}{ Non-pregnant } & age & 27.8 & 12.1 & 24.2 & 7.4 & $\mathrm{~ns}^{\mathrm{c}}$ \\
\hline & litter no & 3.1 & 2.2 & 2.4 & 1.5 & ns \\
\hline \multirow[t]{2}{*}{ Miscellaneous } & age & 28.2 & 17.7 & 28.5 & 9.7 & $\mathrm{~ns}^{\mathrm{c}}$ \\
\hline & litter no & 3.3 & 2.6 & 3.6 & 2.0 & ns \\
\hline \multirow[t]{2}{*}{ Death } & age & 15.4 & 6.9 & 26.6 & 10.9 & * \\
\hline & litter no & 1.4 & 1.3 & 3.1 & 2.1 & ns \\
\hline
\end{tabular}

${ }^{a}$ Main reason for culling

b T-test

c The hypothesis of equal variance was rejected at $p<0.05$ level

d The litter number at culling was limited to six litters

culled earlier than crossbreeds. As stated in the Materials and methods section, the Yorkshire sows were culled after their $6^{\text {th }}$ litter as stated in the study plan ('end of study'), whereas some crossbred sows continued after their $6^{\text {th }}$ litter. The distribution of culling in relation to time of last farrowing was analysed. It was found that more sows were culled within the first 40 days after the last farrowing (i.e. after weaning) than later on. It was mainly culling due to 'locomotory disorders', 'old age', 'miscellaneous' and 'end of study' that took place in this period, whereas 'repeated return to heat' and 'nonpregnant' took place later on. The first category could be regarded as 'voluntary culling' and the second as 'involuntary culling'.

For 41 sows 2 culling reasons were given. Locomotory disorders dominated as second reason $(n=26$, of which 14 had non-pregnant as the main reason), followed by miscellaneous ( $\mathrm{n}$ $=10$, of which 5 had locomotory disorder as the main reason). Four sows were culled due to repeated return to heat with locomotion disorder as second reason.

The influence of leg weakness symptoms in gilts on their longevity

Fig. 2 shows the Kaplan-Meier estimates and Table 6 the results from the final models of the survival analysis of the influence of leg weakness symptoms in gilts at 6 months of age on longevity measured as age at culling due to locomotory disorders as main reason and as either main or secondary reason for culling. 'Breed' was not significant. The leg weakness symptoms were analysed as categorical traits (scores 1, 2 and 3+4). For those included in the final models, a further reduction of categories 
a)

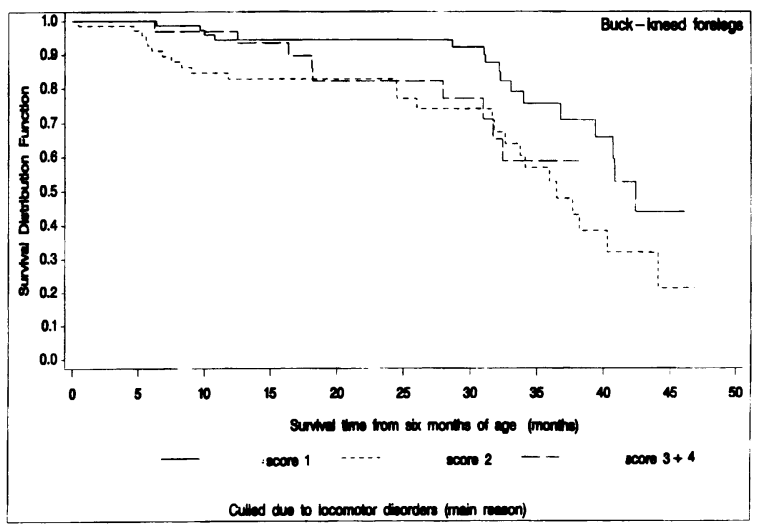

b)

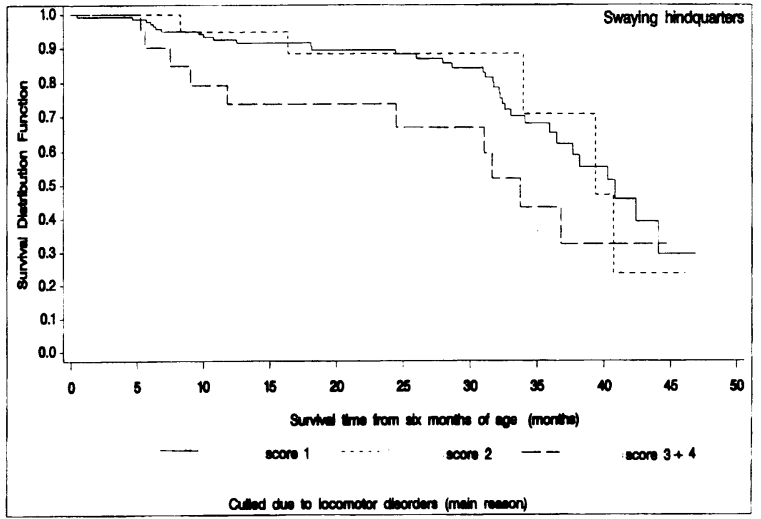

c)

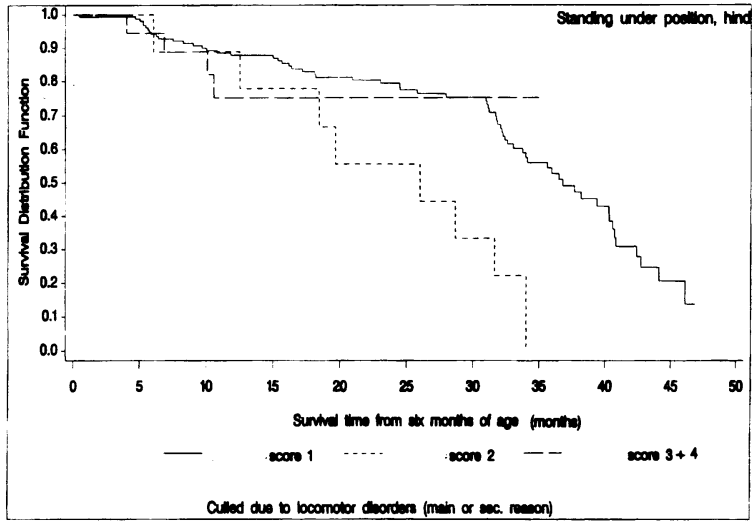

Figure 2. Kaplan-Meier estimates, $\hat{S}(t)$ of the survival function for sows scoring 1,2 and $3+4$ for significant leg weakness symptoms. Survival time in months from 6 months of age.

a) Buck-kneed forelegs b) Swaying hindquarters c) Standing under position, hind. 
Table 6. Influence of leg weakness symptoms in gilts at 6 months of age on their longevity (age at culling) analysed by survival analysis in the final models (backward selection).

\begin{tabular}{|c|c|c|c|c|}
\hline & \multicolumn{3}{|c|}{ Hazard ratios } & $\mathrm{p}$ \\
\hline \multicolumn{5}{|c|}{ Culled due to locomotory disorders (main reason) ${ }^{\mathrm{a}}$} \\
\hline Buck-kneed forelegs & 1 (score 1$)$ & \multicolumn{2}{|c|}{$2.39($ score $2,3,4)$} & 0.006 \\
\hline Swaying hindquarters & $1($ score 1,2$)$ & \multicolumn{2}{|c|}{$2.33($ score 3,4$)$} & 0.02 \\
\hline \multicolumn{5}{|c|}{ Culled due to locomotory disorders (main or secondary reason) ${ }^{\mathrm{b}}$} \\
\hline Standing under position on hind legs & 1 (score 1$)$ & 2.63 (score 2$)$ & $0.79($ score 3,4$)$ & 0.03 \\
\hline
\end{tabular}

${ }^{\mathrm{a}}$ No. of cases $=50 ;$ no. of censorings $=137$.

${ }^{\mathrm{b}}$ No. of cases $=76$; no. of censorings $=111$.

was tried (likelihood ratio test for comparison between models). The hazard ratios for the scoring categories after reduction are shown in Table 6 . The following symptoms were negatively associated with longevity: buck-kneed forelegs, swaying hindquarters and standing under position on hind legs. Interaction effect between the symptoms in the first analysis was not significant. An increased hazard ratio of 2.39 was found for the presence of buck-kneed forelegs (score $>1$ ), and of 2.33 for swaying hindquarters (score $3+4$ versus scores 1 or 2). For standing under position on hind legs the effect on longevity was increased for sows with a score of 2, but not for sows with a score of 3 +4 . These results correspond well with the plots in Fig. 2.

\section{Discussion}

This study was carried out as a prospective cohort study. This study was not a cogent cohort study, however, as the animals could enter into several cohorts simultaneously. It was decided to study the association between scorings at 6 months of age and longevity although the symptoms may vary with time - in agreement with the statements of Liddell (1988): 'To investigate the effects of exposure variables which vary with time, it is essential to base the classification of subcohorts on the variables at the start of the study interval'. The age of 6 months was chosen due to the huge value of this information to selection programs. A disadvantage of the cohort study design is that the incidences (Table 1) are not representative of the population, just as the frequency of culling due to locomotory disorders (Table 4) is probably overestimated. Due to the selective inclusion of animals to the study, the breed differences are artificial. The presentation of data by 'breeds' in Table 1 and Fig. 1 is provided as it is of practical relevance.

\section{Development of leg weakness over time}

The following variables decreased in severity with the age of the animal (parity number) (Fig. 1): buck-kneed forelegs, upright pasterns on hind legs, and steep hock joints, whereas the following increased over time: weak pasterns on fore and hind legs, swaying hindquarters, overgrown claws on accessory digits and brisk movement. These trends are representative of what one would expect to find in practise but are a consequence of culling policy as well as true temporal changes in leg weaknesses. If, for instance, many animals with a high score for buck-kneed forelegs are culled at an early age (as is the case, see Fig. 2), the mean score for the rest would be lower, and it will look as if the variable is decreasing in severity. The results of 
this study confirm the results of Van Steenbergen (1990), who reported that pasterns of fore and rear legs became weaker after the 5th parity, and Hansen et al. (1996), who found that buck-kneed forelegs and upright pasterns decreased over time, while weak pasterns, claws uneven on hind legs and overgrown claws on hind legs increased over time in Landrace sows.

It is interesting that although only $12 \%$ of the gilts showed a middle severe to severe degree of stiff locomotion (Table 1), this problem increased in incidence so that half of the sows had suffered from a stiff locomotion and nearly one third had been distinctly lame at some time in their life (Table 2) although none of the gilts were lame at the beginning of the study. This indicates that leg weakness should be an important aspect of any serious consideration of sow welfare.

\section{Mutual associations between leg weakness traits}

The analysis of the associations between leg weakness symptoms and some locomotory problems (Table 3) showed that buck-kneed forelegs, upright pasterns, legs turned out, standing under position and swaying hindquarters were associated with locomotory problems, whereas weak pasterns on hind legs and splayed digits were associated with brisk movement (freedom from locomotor problems). Contrary to stiff movement that was already seen at 6 months of age (especially stiff in rear), lameness did not occur until the first parity (Fig. 1). This is due to the fact that animals being lame at 6 months of age were excluded from the study in order to avoid animals suffering from arthritis as far as possible. As the maximal scores over time for each sow were used for both the dependent and independent variables, they were not necessarily present simultaneously, which means that one variable could have been previous to the other. In agreement with these results, Grøndalen (1974) found that pigs having weak pasterns on front legs achieved the best gait score.

\section{Culling reasons}

Corresponding to results by Dagorn \& Aumaitre (1979), Cederberg \& Jonsson (1996), Sehested \& Schjerve (1996), Kangasniemi (1996), Pedersen (1996), and Paterson et al. (1996), reproduction problems (i.e. repeated return to heat and non-pregnant) was the most frequent reason followed by locomotory disorders (Table 4).

There were large differences in mean age and number of litters at culling between 'breeds', as Yorkshire sows were culled at a considerably lower age (average parity: 2.94) than crossbreeds (Landrace*Yorkshire) (average parity: 4.11) (Table 5). This difference was found for culling due to 'locomotory disorders' and 'repeated return to heat'. This agrees with findings of Jones (1967), Sehested \& Schjerve (1996) and Kangasniemi (1996) The present study included sows which were culled before the first mating or which had been mated but not yet farrowed for the first time, i.e. parity 0 . The above-mentioned studies do not state whether they include sows removed at parity 0 , which makes comparisons difficult. In contrast, Dagorn \& Aumaitre (1979) reported no difference in age at culling between Large White (Y) and crossbreeds (YL), but significantly more Landrace sows were culled, especially due to locomotor disorders.

Culling after weaning is normally a planned (voluntary) culling (Pedersen 1996). In this study, culling due to 'locomotor disorders', 'old age', 'miscellaneous' and 'end of study' mainly took place within the first 40 days after farrowing (i.e. after weaning) and could be regarded as voluntary culling, while culling due 
to 'repeated return to heat' and 'non-pregnant' occurred after this period (involuntary culling). Sehested \& Schjerve (1996) also reported reproduction problems as reasons for involuntary culling. Locomotor disorders are, at least in commercial herds, an involuntary reason for culling, but it is not acute enough to call for immediate culling.

\section{Influence of leg weakness on longevity}

In this paper only functional longevity was considered, as the main objective was locomotory problems. As culling due to locomotory problems could be an underlying (secondary) reason for culling ( 26 out of 41 cases where 2 reasons for culling were given), survival analyses of sows culled due to locomotory problems as either the main or secondary reason were also done. Buck-kneed forelegs and swaying hindquarters were found to influence longevity, whereas the results concerning standing under position were less distinct, probably because of the sample size (Table 6). Only animals from one herd were included in this study. In this herd, the sows were tied up during gestation. This may conceal some cases of leg problems since these are most easily diagnosed when the sow is walking. In herds with loose sows, leg problems will therefore probably result in earlier culling of the animals. Although this study does not comprise different housing systems or pedigree herds, the results concerning the significance of leg weakness symptoms on longevity confirm results reported by Van Steenbergen (1990) who found that swaying hindquarters and bowed legs were unfavourably correlated with longevity. Grindflek \& Sehested (1996) reported that standing under position and straight (upright) pasterns on fore and hind legs resulted in decreased longevity and that weak pasterns had a positive effect on longevity.

In the pig breeding programmes of today, conformation is included as a breeding goal in Denmark (Andersen \& Hansen 1996) and Sweden (Lundeheim 1996) in the form of a scoring of the overall appearance of pigs (exterior) at 5 to 6 months of age. The results in this and the following paper (Jørgensen 2000) provide further information on which leg weakness symptoms to concentrate on in order to improve the longevity and welfare of sows.

It is concluded that:

- although only $10 \%$ of the gilts showed a stiff locomotion, half of the sows had suffered from this and nearly one third had been distinctly lame at some time in their life

- buck-kneed forelegs, upright pasterns, legs turned out, standing under position and swaying hindquarters are the main leg weaknesses associated with stiff locomotion or lameness, whereas weak pasterns on hind legs and splayed digits were associated with brisk movement (freedom from locomotor problems)

- buck-kneed forelegs, swaying hindquarters, and standing under position were negatively associated with longevity.

\section{Acknowledgements}

This investigation was carried out in the research herd 'Grønhøj' owned by the Federation of Danish Pig Producers and Slaughterhouses. The staff of this herd were very helpful during the practical part of the investigation. I. R. Korsgaard has provided helpful comments regarding the statistics and N. Friggens provided valuable comments on the manuscript. They are gratefully acknowledged for their assistance. The investigation was supported by the Federation of Danish Pig Producers and Slaughterhouses.

\section{References}

Andersen S, Hansen UG: Selection for conformation and longevity in the Danish breeding system. Proceeding of NJF-seminar no. 265: Longevity of Sows. Research Centre Foulum, Denmark. 27.-28. March 1996, 72-76. 
Bereskin B: Genetic aspects of feet and legs soundness in swine. J.Anim.Sci. 1979, 48, 13221328.

Cederberg ER, Jonsson L: Sow culling in Sweden. Proceedings of NJF-seminar no.265 "Longevity of Sows". Research Centre Foulum, Denmark, 27.-28. March 1996, 7-8.

Christensen G, Vraa-Andersen L, Mousing J: Causes of mortality among sows in Danish pig herds. Vet.Rec. 1995, 137, 396-399.

D'Allaire S, Stein TE, Leman AD: Culling patterns in selected Minnesota swine breeding herds. Can.J.Vet.Res. 1987, 51, 506-512.

Dagorn J, Aumaitre A: Sow culling: reasons for and effect on productivity. Livest.Prod.Sci. 1979, 6, 167-177.

Dagorn J, Vaudelet MR: Elevage et ses résultats: les résultats de Gestion Technique des Troupeaux de Truies, année 1992. Techni-Porc 1993, 13, 9-14.

Ducrocq V: An analysis of length of productive life in dairy cattle. PhD thesis, 1987, Cornell Univ. Ithaca, NY.

Ducrocq V, Quaas RL, Pollak EL, Casella G: Length of productive life of dairy cows. 2. Variance component estimation and sire evaluation. J. Dairy Sci. 1988, 71, 3071-3079.

Grindflek E, Sehested E: Conformation and longevity in Norwegian pigs. Proceeding of NJFseminar no. 265: Longevity of Sows. Research Centre Foulum, Denmark. 27.-28. March 1996, 77-84.

Grøndalen T: Leg weakness in pigs. I. Incidence and relationship to skeletal lesions, feeding level, protein and mineral supply, exercise and exterior conformation. Acta vet.scand. 1974, 15, 555573.

Hansen UG, Gudmandsen AB, Arnbjerg J, Bittegeko $S B P R$ : Ledforandringers udvikling (Astrupforsøget). (The trend of development of osteochondrosis (The Astrup-investigation). Meddelelse A2/96. Landsudvalget for svin., Copenhagen, 1996.

Jones JET: An investigation of the causes of mortality and morbidity in sows in a commercial herd. Br.vet.J. 1967, 123, 327-339.

Jørgensen B: Osteochondrosis / osteoarthrosis and claw disorders in sows, associated with leg weakness. Acta vet.scand. 2000, 41, 123-138.

Jørgensen B, Sørensen MT: Different rearing intensities of gilts. II. Effects on subsequent leg weakness and longevity. Livest.Prod.Sci. 1998, $54,167-171$.
Jørgensen B, Vestergaard $T$ : Genetics of leg weakness in boars at the Danish pig breeding stations. Acta Agric.Scand. 1990, 40, 59-69.

Kangasniemi $R$ : Reasons of culling of sows in the Finish sow recording scheme. Proceeding of NJF-seminar no. 265: Longevity of Sows. Research Centre Foulum, Denmark. 27.-28. March 1996, 17-27.

Karlberg K: Utrangeringsårsaker hos avlspurker. (Culling reasons in breeding animals). Norsk Veterinærtidsskrift 1979, 91, 423-426.

Liddell FDK: The development of cohort studies in epidemiology: A review. J.Clin.Epidemiol. 1988, 41, 1217-1237.

Lodde vKH, Dzapo V, Wassmuth R: Untersuchungen über Exterieurbeanstandungen bei der Körung von Jungebern. II. Beziehungen zwischen Exterieurbeanstandungen und Leistungsmerkmalen sowie genetische Disposition der Exterieurbeanstandungen. Züchtungskunde 1985, 57, 47-57.

Lundeheim N: Genetic analysis of osteochondrosis and leg weakness in the Swedish pig progeny testing scheme. Acta Agric.Scand. 1987, 37, 159173.

Lundeheim N: Conformation scoring in the Swedish pig progeny testing scheme. Proceeding of NJFseminar no. 265: Longevity of Sows. Research Centre Foulum, Denmark. 27.-28. March 1996, 70-71.

Nielsen NC: Arthrosis in pigs. Nord.Vet.-Med. 1973, 25, 17-27.

Paterson R, Cargill C, Pointon A: Investigating into deaths and excessive culling of sows in Australian pig herds. Proceeding of NJF-seminar no. 265: Longevity of Sows. Research Centre Foulum, Denmark. 27.-28. March 1996, 34-45.

Pedersen PN: Longevity and culling rates in Danish sow production and consequences of different strategies for culling. Proceeding of NJF-seminar no. 265: Longevity of Sows. Research Centre Foulum, Denmark. 27.-28. March 1996, 28-33.

Penny RHC: Locomotor dysfunction causing reproductive failure. In: DA Morrow. (Ed.): Current therapy in theriogenology. W.B. Saunders, Philad. Pa., 1980, 1041-1045.

Rothschild MF, Christian LL, Jung Y-C: Genetic control of front-leg weakness in Duroc swine. II Correlated responses in growth rate, backfat and reproduction from five generations of divergent selection. Livest.Prod.Sci. 1988, 19, 473-485.

SAS Institute Inc.: SAS/STAT ${ }^{\mathrm{TM}}$ User's Guide, Ver- 
sion 6, 4th edn. SAS Institute Inc., Cary, N.C. 1989.

Sehested E, Schjerve A: Aspects of sow longevity based on analysis of Norwegian sow recording data. Proceeding of NJF-seminar no. 265: Longevity of Sows. Research Centre Foulum, Denmark. 27.-28. March 1996, 9-16.

Stein TE, Dijkhuizen A, D'Allaire S, Morris RS: Sow culling and mortality in commercial swine breeding herds. Prev.Vet.Med. 1990, 9, 85-94.

Svendsen J, Nielsen NC, Bille N, Riising H-S: Causes of culling and death in sows. Nord.Vet.-Med. 1975, 27, 604-615.

Van Steenbergen EJ: Relevance of exterior appraisal in pig breeding. PhD thesis, 1990, Wageningen Agricultural University, The Netherlands.

Webb AJ, Russel WS, Sales DI: Genetics of leg weakness in performance-tested boars. Anim. Prod. 1983, 36, 117-130.

\author{
Sammendrag \\ Holdbarhed hos søer $i$ relation til bensvagheds- \\ symptomer ved seks måneders alderen.
}

Formålet med undersøgelsen var at klarlægge indflydelsen af forskellige bensvaghedssymptomer målt tidligt i dyrenes liv (6 måneders alder) på deres senere holdbarhed målt som alder ved udsættelse pga. benproblemer. 187 gylte med forskellige bensvaghedssymptomer ved 6 måneders alderen blev fulgt indtil udsættelse og bedømt for bensvaghed én gang i hver drægtighed på en skala fra 1 (normal) til 4 (svære forandringer). Alder ved udsættelse og de primære og eventuelle sekundære årsager til udsættelse blev registreret. Indflydelsen af bensvaghedssymptomer på holdbarhed blev analyseret med overlevelsesanalyse. $12 \%$ af gyltene blev udvalgt med stiv bevægelse i 6 måneders alderen; frekvensen steg derefter, således at halvdelen af dyrene udviste stiv bevægelse i løbet af deres levetid og en trejdedel blev decideret halte. Krumme forben, stejle koder, udaddrejede forben, understillede bagben og svingende bagpart var associeret med stiv bevægelse og/eller halthed, mens bjørnefodethed (slappe koder) på bagben og spredeklove på forben var associeret med en livlig gang (fravær af bevægelsesproblemer). Følgende bensvaghedssymptomer fandtes at have en signifikant negativ indflydelse på holdbarhed: krumme forben, svingende bagpart og understillede bagben.

(Received July 26, 1999; accepted January 7, 2000).

Reprints may be obtained from: B. Jørgensen, Danish Institute of Agricultural Sciences, Research Centre Foulum, P.O. Box 50, DK-8830 Tjele, Denmark. E-mail: bente.jorgensen@agrsci.dk, tel: +45 899913 18, fax: +4589991500 . 